\title{
Evaluation of Strain, Dietary Energy Level and Stocking Density on Broiler Feathering
}

Author(s)
Moreira J1
Mendes $A^{2}{ }^{2}$
Garcia RG
Garcia EA ${ }^{2}$
Roça RO ${ }^{4}$
Nääs IA
Dalanezi JA3
Pelícia K ${ }^{3}$
1 Professor, Departamento de Zootecnia -
FCA/UFVJM, Diamantina - MG; Post-Doc at
DPEA, FMVZ/UNESP, Botucatu, SP.
2 Professor, Departamento de Produção e
Exploração Animal, FMVZ/UNESP, Botucatu,
SP.
3 Graduate Student, Departamento de
Produção e Exploração Animal, FMVZ/
UNESP, Botucatu, SP.
4 Professor, Departamento de Gestão e
Tecnologia Agroindustrial, FCA/UNESP,
Botucatu, SP.
5 Professor, Departamento de Construções
Rurais, FEAGRI/UNICAMP, Campinas, SP.

Mail Address

Joerley Moreira

Departamento de Zootecnia

FCA/UFVJM - Campus de Diamantina

Travessa das Camélias, 38 - Jardim

39.100-000. Diamantina, MG, Brazil

Telephone: +55 +14 38117189

$+55+3835311842$

Email: joerley@fca.unesp.br joerley@fafeid.edu.br

\section{Keywords}

Broiler chickens, dietary energy, feathering, strain, stocking density.

\section{ABSTRACT}

This study evaluated the effects of strain, stocking density and dietary energy level on the feathering of broiler chickens. Four trials were carried out between September 2000 and April 2002. There were 10,685 broiler chicks from the strains Ross 308, Cobb 500, Hybro PG, Hubbard, MPK, and Isa Vedette. The bids were reared at stocking densities varying between 10 and 16 birds $/ \mathrm{m}^{2}$ and were given diets containing different metabolizable energy levels. Broiler feathering was evaluated either by atrributing scores from 1 to 10 to feather covering along the thigh and back (visual inspection), or by determining the percentage weight of the feathers at 28 and 42 days of age. Increasing rearing densities resulted in poorer feathering, mainly if 12 or $13 \mathrm{birds} / \mathrm{m}^{2}$ were compared with $16 \mathrm{birds} / \mathrm{m}^{2}$. The strains showed different feathering; it was better in Cobb 500 and MPK birds, whereas Hubbard birds showed poorer feathering, mostly along the back. The energy level in the diet has also affected feathering scores. Medium energy level resulted in better feathering along the back at 28 days, and the low level, in better feathering along the thigh at 35 days of age. Finally, feather scores were better in females than in males.

\section{INTRODUCTION}

Breeding programs have influenced feathering rate in modern broiler chickens. Slow-feathering $(K)$ and rapid-feathering $(K)$ genes have been introduced more than 20 years ago as a means to enable sex determination in one-day-old chicks. The final hybrid characterizes the feather sexable commercial broiler chicken. One-day-old fast-feathering females may be distinguished from slow-feathering males because the former show primary wing feathers longer than the coverts. On the other hand, primary wing feathers are the same size as the coverts in males. Therefore, sexing one-day-old chicks became a standard procedure at the hatchery and allowed sex-separate rearing. The difference in feather size is less evident after 3 to 4 days of age and is no longer reliable as a means to sex the birds.

Nutrition may affect not only feathering rate, but also the structure and color of feathers. Deficiency of some vitamins and trace minerals might induce abnormal feathers, as well as the presence of micotoxins in the diet. Some viruses, bacteria and mycoplasmas might infect the feather follicle and affect feathering (Leeson \& Walsh, 2004b).

Feathers play an important role in thermoregulation, comprising an efficient external covering: they increase thermal insulation and allow birds to maintain their body temperature in cold regions. On the other hand, the feather covering impairs heat dissipation in hot environments and the naked areas of the body are important for thermoregulation (Macari, 2001). Good feather covering is necessary for the quality of 
Moreira J, Mendes AA, Garcia RG,

Garcia EA, Roça RO, Nääs IA,

Dalanezi JA, Pelícia K

Evaluation of Strain, Dietary Energy Level and Stocking Density on Broiler Feathering

dressed carcass, since poor feathering may result in breast blisters, presence of crusts, cellulitis, skin scratches, bruises and laceration, and other tissue traumas that might cause carcass downgrading during processing (Edens, 2000; Brake, 2001).

Feather weight might vary from 3 to $6 \%$ of adult body weight in the modern broiler strains (Leeson \& Walsh, 2004a). The feathering rate increases naturally and linearly with aging, as shown by McDougald \& Keshavarz (1984). Feather growth is an energetically demanding process that uses nutrients from metabolic and dietary sources (Edens, 2000). Kuenzel \& Kuenzel (1977) compared the basal metabolic activity of laying hens and broiler chickens in regard to the energy for maintenance and production, and reported that laying hens showed higher metabolic requirements during the first eight weeks in comparison to broiler chickens. Nevertheless, the same evaluation considering the metabolic body weight has shown that differences were present only in the first three to four weeks. After three weeks, the feather covering is almost complete in laying hens, but not in broilers. Since feathering is earlier in hens, there is greater metabolic activity. According to the data published by Kuenzel \& Kuenzel (1977), the costs of feather production are approximately $40 \mathrm{kcal} / \mathrm{g}$ in laying hens and $60 \mathrm{kcal} / \mathrm{g}$ in broiler chickens $(29 \%$ and $38 \%$ of daily energy intake, respectively).

Environment temperature also affects bird feathering. Cooper \& Washburn (1998) reported significant poorer feathering in broilers kept under high temperature. Yalcin et al. (1997) showed that birds have better feathering in the summer (mean temperature of $27^{\circ} \mathrm{C}$ ) than in the winter (mean temperature of $20^{\circ} \mathrm{C}$ ). It was suggested that the birds might have more peripheral blood during the summer, thus, the process of feathering would be favored due to the greater supply of nutrients delivered to the feather follicles. This effect might occur when the birds are submitted to high stocking density, since the temperature in the rearing environment increases. Nevertheless, bird stress would also increase. According to Cahaner et al. (1993), broilers carrying the nakedneck gene $(\mathrm{Na})$ are poorly feathered but show improved performance in high temperatures. Male broilers from commercial strains with rapid growth showed less weight gain than females at high temperatures $\left(32^{\circ} \mathrm{C}\right)$ (Cahaner \& Leenstra, 1992).

Problems of poor feathering still occur in modern broiler chicken strains, due to nutrition, management or genetics. Whereas some commercial broilers show complete feathering approximately at 50 days of age, feather growth is generally still in progress at that age. This late or deficient feathering might impair carcass quality and affect bird growth, as previously explained.

There is much information about the non-genetic factors that affect feather formation, such as hormones, vitamins, minerals and mainly amino acids (Boone et al. 1950; Harrap \& Woods, 1967; Arnold et al. 1974; Moran 1981; Gous et al. 1999; Edens et al. 2000a; Edens et al. 2000b). Nevertheless, the availability of information in regard to different commercial strains, stocking density and even the influence of dietary energy levels are scarce and limited.

Poor feathering in broiler chickens may be sometimes due to inadequate nutrition, such as inaccurately formulated diets with deficient or excessive levels of amino acids, minerals or vitamins. On the other hand, non-nutritional factors, such as genetic inheritance and environment, play a vital role in the feathering rate, and might also contribute to poor feathering. Therefore, the objective of the present study was to evaluate the effects of strain, stocking density and dietary energy level on the feathering of broiler chickens.

\section{MATERIAL AND METHODS}

The data used herein had been collected during four trials carried out at Faculdade de Medicina Veterinária e Zootecnia, UNESP, Campus de Botucatu. Although the primary objective of these previous trials was not feather evaluation, this parameter had been assessed and the data were gathered in the present study.

Trial 1: this trial was carried out from September to November 2000. One-day-old Ross 308 chicks $(n=3,120)$ were sexed and distributed according to a completely randomized design in a $3 \times 2$ factorial design, using three stocking densities $(10,13$ and 16 birds $/ \mathrm{m}^{2}$ ) and two sexes, with six repetitions and variable number of birds per repetition according to the density. A four-phase feeding program was used: pre-initial (1-7 days), initial (7-21 d), growing (21-37 d) and final (37-42 d).

Trial 2: the trial was carried out from April to May 2001. One-day-old chicks $(n=2,925)$ were sexed and distributed according to a completely randomized design in a $3 \times 3$ factorial design, using three strains (Ross 308, Cobb 500 and Hybro PG) and three densities $\left(10,13\right.$ and 16 birds $\left./ \mathrm{m}^{2}\right)$, with four repetitions and variable number of birds according to the density. Three 
Moreira J, Mendes AA, Garcia RG,

Garcia EA, Roça RO, Nääs IA,

Dalanezi JA, Pelícia K

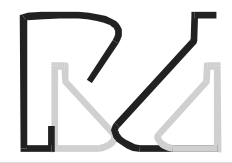

phases were considered: initial (1-21d), growing (21$35 \mathrm{~d})$ and final (35-42 d).

Trial 3: From October to December 2001, 2,240 one-day-old Hybro PG male chicks were distributed according to a completely randomized experimental design in a $2 \times 4$ factorial: two densities (12 and 16 birds $/ \mathrm{m}^{2}$ ) and four energy levels in the diet (low, standard, medium and high), with four repetitions and variable number of birds per repetition, according to the rearing density. The metabolizable energy levels $(\mathrm{kcal} / \mathrm{kg})$ in the four rearing phases were: 2950,3000 , 3050 and 3100 (initial); 3050, 3100, 3150 and 3200 (growing); 3150, 3200, 3250 and 3300 (final). The standard level was similar to levels used in commercial poultry rearing.

Trial 4: the experiment was carried out from February to April, 2002. Two thousand and four hundred one-day-old chicks were sexed and distributed in a completely randomized experimental design according to a $5 \times 2$ factorial, using five strains and two sexes, with four repetitions of 60 birds. Two conventional strains (MPK and Isa Vedette) and three conformational strains (Ross 308, Cobb 500 and Hubbard) were used.

All trials were carried out in an experimental poultry house covered with asbestos tiles measuring $8 \times 40 \mathrm{~m}$, with $3.5 \mathrm{~m}$ of height. The house comprised 48 pens with $5 \mathrm{~m}^{2}(3.25 \times 1.55 \mathrm{~m})$. The pens were separated by a 40-cm masonry wall and equipped with two 20$\mathrm{kg}$ automatic feeders and a bell drinker. Side masonry walls measured $40 \mathrm{~cm}$ and a wire mesh covered the side openings, which were protected by curtains. The poultry house was equipped with fans to enable homogeneous ventilation to all pens.

The diets used in all trials were formulated according to Rostagno et al. (2000). The recommended energy level was changed to provide the experimental energy levels and diets were adjusted in Trial 3. Birds were fed water and diet ad libitum throughout the experimental period.

Two different methods were used to evaluate feathering: scores were given by visual analysis or feather weight was expressed as a function of the live weight of the birds. Scoring was performed following the feather scores provided by AGROCERES - Rio Claro, SP, Brazil, as shown in Figures 1 and 2. Samples were taken randomly from 20 birds per repetition at 28, 37 and 42 days of age in Trial 1, at 28 days old in Trials 2 and 4 , and at 28 and 35 days in Trial 3. Both back and thigh feathering were scored and recorded. Scores ranged between 0 and 10, according to the degree of
Evaluation of Strain, Dietary Energy Level and Stocking Density on Broiler Feathering

feathering shown in the two body areas. The ages of evaluation varied as a function of the feathering observed at 28 days of age. In each trial, feathering was assessed in the same birds at the different ages. Feather relative weight was evaluated at 28 days in Trial 2, and at 28 and 35 days old in Trial 3. The technique had not been standardized when Trial 1 was carried out and the number of birds in Trial 4 was not enough to use it. Therefore, evaluation was made only by score in these two trials. The relative weight technique was adapted from Lowe \& Merkley (1986). Three birds were taken from each repetition and replacement birds were used to keep density constant. Leg-banded birds were taken to the slaughterhouse (Abatedouro Experimental de Aves, Faculdade de Medicina Veterinária e Zootecnia - UNESP, Campus de Botucatu) and killed by electrical shock to avoid blood loss during picking. The body+feather weight was recorded before picking. Birds were scalded at $50^{\circ} \mathrm{C}$ and care was taken not to remove the leg cuticle. Visual inspection was performed after picking and any feather residues were manually removed. The carcass was dried with paper towel and body weight without feathers was recorded. Feather weight was obtained by the difference between the body weight before and after picking and expressed as the percentage of total body weight, as follows:

Feather weight $=$ Body weight with feathers - body weight without feathers

Feather percentage $=$ (Feather weight $/$ body weight with feathers) * 100

The results of score evaluation were statistically analyzed using the non-parametric method of KruskalWallis (Sampaio, 1998) and feather percentage data were analyzed using the SAS GLM procedure (SAS Institute, 1996).

\section{RESULTS AND DISCUSSION}

\section{Trial 1}

Table 1 shows the results from Trial 1 . Stocking density affected $(p<0.05)$ feathering only at 28 days of age, so that increasing densities resulted in poorer feathering along the back in females and along the thigh in males. Although feathering was not affected ( $p>0.05)$ after 28 days of age, there was a quantitative reduction in back and thigh feathering in 37-day-old males reared at higher densities. In the final phase of rearing (37 to 42 days), feathering was almost 
Moreira J, Mendes AA, Garcia RG, Garcia EA, Roça RO, Nääs IA, Dalanezi JA, Pelícia K

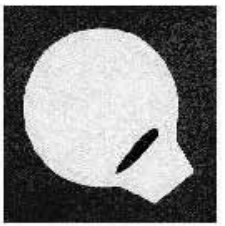

1

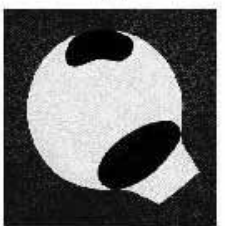

4

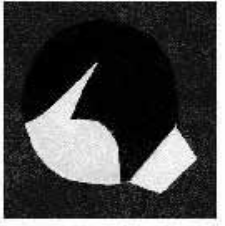

7

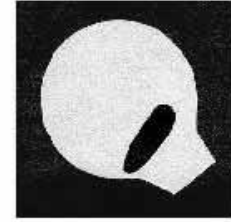

2

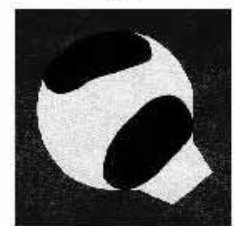

5

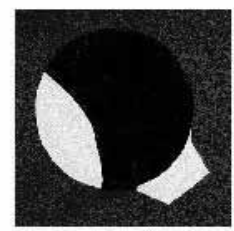

8

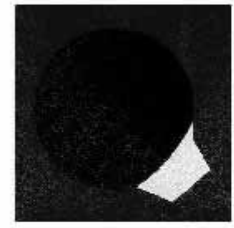

10
Figure 1 - Scores of thigh feathering

\begin{tabular}{|c|c|c|c|c|}
\hline \multirow{2}{*}{$\begin{array}{l}\text { Density } \\
\left(\text { birds } / \mathrm{m}^{2}\right)\end{array}$} & \multicolumn{2}{|c|}{ Back } & \multicolumn{2}{|c|}{ Thigh } \\
\hline & Male & Female & Male & Female \\
\hline \multicolumn{5}{|c|}{28 days } \\
\hline 10 & 5.55 & $6.60^{a}$ & $4.75^{\mathrm{a}}$ & 5.58 \\
\hline 13 & 5.65 & $6.65^{a}$ & $4.75^{\mathrm{a}}$ & 5.65 \\
\hline 16 & 5.35 & $6.18^{b}$ & $4.38^{b}$ & 5.50 \\
\hline \multicolumn{5}{|c|}{37 days } \\
\hline 10 & 8.33 & 9.60 & 7.08 & 8.35 \\
\hline 13 & 8.08 & 9.48 & 7.03 & 8.05 \\
\hline 16 & 7.80 & 9.55 & 6.55 & 8.23 \\
\hline \multicolumn{5}{|c|}{42 days } \\
\hline 10 & 9.58 & 10.00 & 8.45 & 9.28 \\
\hline 13 & 9.75 & 10.00 & 8.28 & 9.20 \\
\hline 16 & 9.68 & 9.98 & 8.38 & 9.25 \\
\hline
\end{tabular}

1 - Within each age, means followed by different letters in the columns are different by the Kruskal-Wallis test $(p<0.05)$.

complete along the back and thigh of females. On the other hand, feathering in the males was not complete in this phase and it was better on the back than on the thigh. Therefore, feathering evaluation is not justifiable in females after 28 days of age, since the earlier
Evaluation of Strain, Dietary Energy Level and Stocking Density on Broiler Feathering

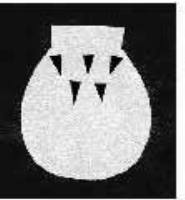

1

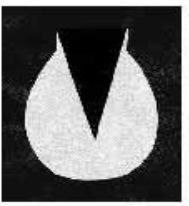

4

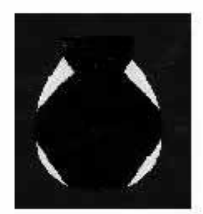

7

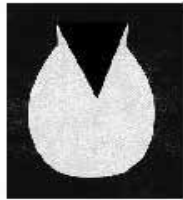

2

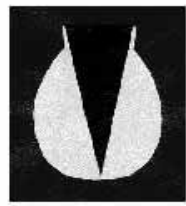

5

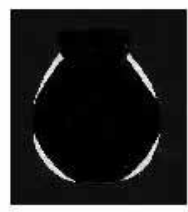

8

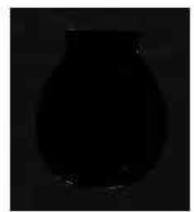

10

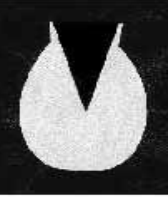

3

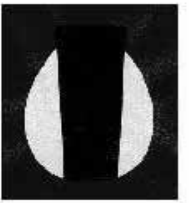

6

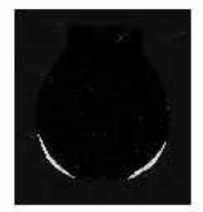

9
Figure 2 - Scores of back feathering.

feathering is almost maximized at 28 days. On the other hand, evaluation might be performed after that age in males, since feathering is completed only later.

\section{Trial 2}

Thigh feather score was lower $(p<0.05)$ in the females kept at higher densities (Table 2). Strain affected $(p<0.05)$ back feathering in males. Cobb 500 showed better score compared to strains Ross 308 and Hybro PG, which showed similar scores ( $p>0.05$ ). Numerically higher scores were seen on the back of females and thigh of males from Cobb 500 strain. In regard to feathering evaluated by the relative weight of feathers, there were no significant differences ( $p>0.05)$ due to density or strains. It should be noted that feathering in Ross 308 was better when density increased from 10 to $13 \mathrm{birds} / \mathrm{m}^{2}$, although it became poorer from 13 to $16 \mathrm{birds} / \mathrm{m}^{2}$. On the other hand, feathering was poorer in Cobb 500 when density increased from 10 to $13 \mathrm{birds} / \mathrm{m}^{2}$ and then improved from 13 to 16 birds $/ \mathrm{m}^{2}$. Increasing density resulted in better feathering in Hybro PG males. Therefore, data 
Moreira J, Mendes AA, Garcia RG, Garcia EA, Roça RO, Nääs IA, Dalanezi JA, Pelícia K showed greater variability and lower consistency when evaluated by means of relative feather weight compared to feather score evaluation.

\begin{tabular}{|c|c|c|c|c|c|}
\hline \multirow{2}{*}{ Factors } & \multicolumn{3}{|c|}{ Back } & \multicolumn{2}{|c|}{ Thigh } \\
\hline & Male & & & Male & Female \\
\hline \multicolumn{6}{|c|}{ Score evaluation ${ }^{1}$} \\
\hline \multicolumn{6}{|c|}{ Density (birds/m²) } \\
\hline 10 & 7.40 & \multirow{2}{*}{\multicolumn{2}{|c|}{$\begin{array}{l}9.63 \\
9.57\end{array}$}} & 7.30 & $8.00^{\mathrm{a}}$ \\
\hline 13 & 7.33 & & & 7.40 & $7.60^{\mathrm{b}}$ \\
\hline 16 & 7.07 & \multicolumn{2}{|c|}{9.73} & 7.03 & $7.43^{b}$ \\
\hline \multicolumn{6}{|c|}{ Strains } \\
\hline Ross 308 & $7.07^{b}$ & \multicolumn{2}{|c|}{9.70} & 7.27 & 7.70 \\
\hline Cobb 500 & $8.00^{a}$ & \multicolumn{2}{|c|}{9.80} & 7.43 & 7.60 \\
\hline Hybro PG & $6.77^{\mathrm{b}}$ & \multicolumn{2}{|c|}{9.43} & 7.03 & 7.73 \\
\hline \multicolumn{6}{|c|}{ Relative weight feathering $(\%)^{2}$} \\
\hline \multirow[t]{2}{*}{ Strains } & Sex & \multicolumn{3}{|c|}{ Density (birds $/ \mathrm{m}^{2}$ ) } & Mean \\
\hline & & 10 & 13 & 16 & \\
\hline \multirow[t]{3}{*}{ Ross 308} & Male & 5.30 & 5.78 & 5.11 & $5.39 B$ \\
\hline & Female & 6.77 & 6.81 & 6.26 & $6.61 \mathrm{~A}$ \\
\hline & Mean & 6.03 & 6.29 & 5.68 & \\
\hline \multirow[t]{3}{*}{ Cobb 500} & Male & 5.75 & 5.40 & 5.98 & 5.71 \\
\hline & Female & 7.40 & 6.79 & 6.38 & 6.85 \\
\hline & Mean & 6.58 & 6.09 & 6.18 & \\
\hline \multirow[t]{3}{*}{ Hybro PG } & Male & 4.93 & 5.11 & 5.49 & $5.18 \mathrm{~B}$ \\
\hline & Female & 6.47 & 6.33 & 6.47 & $6.42 \mathrm{~A}$ \\
\hline & Mean & 5.69 & 5.72 & 5.98 & \\
\hline CV (\%) & & & 16.15 & & \\
\hline
\end{tabular}

1 - Within each factor, means followed by different letters in the columns are different according to the Kruskal-Wallis test $(p<0.05) .2$ - Within strains, means followed by different letters in the columns are different according to the test of Tukey $(p<0.05)$.

Sex influenced $(p<0.05)$ feathering in Ross 308 and Hybro PG birds. Females showed better feathering than males from both strains. Cobb 500 females also showed greater percentage of feathering than males, although there were no significant differences $(p>0.05)$.

\section{Trial 3}

Back score was significantly different $(p<0.05)$ in 28-day-old birds reared at $16 \mathrm{birds} / \mathrm{m}^{2}$; birds fed medium energy levels showed better feathering and birds fed low energy had poorer feathering scores (Table 3). Thigh feathering scores were also different $(p<0.05)$ in the birds reared at 16 birds $/ \mathrm{m}^{2}$, but differences were seen only at 35 days of age. Birds fed low energy level showed the best feathering score, contrarily to 28-day-old results. Energy levels and densities had no effect $(p<0.05)$ on relative feather weight. Nevertheless, similarly to the results of thigh feathering at 35 days old, birds fed low energy level presented higher relative feather weight.

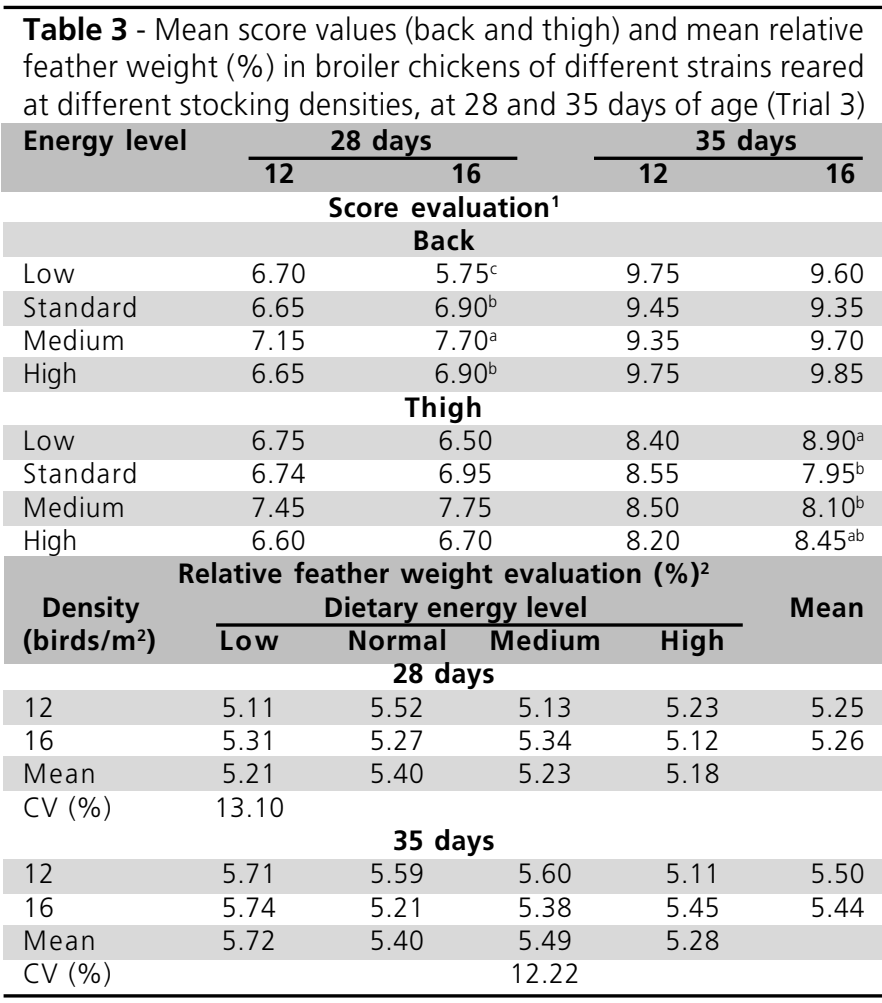

1 - Means followed by different letters in the columns are different according to the Kruskal-Wallis test $(p<0.05) .2$ - Means followed by different letters in the columns are different according to the test of Tukey $(p<0.05)$.

\section{Trial 4}

Feathering was different $(p<0.05)$ between strains in Trial 4 (Table 4). Independent of sex, back feathering in Cobb 500 birds was better, whereas Hubbard feathering was poorer. Ross 308, MPK and Isa Vedette showed similar feather score, which was poorer than Cobb 500 (males) and better than Hubbard (males and females). The evaluation of thigh feathering was better in MPK strain, both in males and females. On the other hand, Hubbard and Ross 308 birds showed poorer feathering in males and females, respectively.

\begin{tabular}{|c|c|c|c|c|}
\hline \multirow[t]{2}{*}{ Strains } & \multicolumn{2}{|c|}{ Back feathering } & \multicolumn{2}{|c|}{ Thigh feathering } \\
\hline & Male & Female & Male & Female \\
\hline Ross 308 & $7.73^{b}$ & $9.52^{b c}$ & $7.03^{b}$ & $7.23^{c}$ \\
\hline Cobb 500 & $8.14^{\mathrm{a}}$ & $9.70^{\mathrm{a}}$ & $7.29^{a b}$ & $7.60^{\mathrm{ab}}$ \\
\hline Hubbard & $7.21^{\mathrm{c}}$ & $9.31^{c}$ & $6.65^{c}$ & $7.53^{\mathrm{ab}}$ \\
\hline MPK & $7.76^{b}$ & $9.66^{a b}$ & $7.31^{\mathrm{a}}$ & $7.76^{a}$ \\
\hline Isa Vedette & $7.73^{b}$ & $9.54^{\mathrm{ab}}$ & $7.06^{a b}$ & $7.52^{b}$ \\
\hline
\end{tabular}

Means followed by different letters in the columns are different by the Kruskal-Wallis test $(p<0.05)$.

In general, the results showed poorer feathering $(p<0.05)$ when stocking density was increased from 
Moreira J, Mendes AA, Garcia RG, Garcia EA, Roça RO, Nääs IA, Dalanezi JA, Pelícia K
10 to $16 \mathrm{birds} / \mathrm{m}^{2}$. Therefore, the increase in stocking density requires careful consideration regarding the feather cover of birds, since the number of downgraded carcasses might increase due to poor feathering. Proudfoot \& Hulan (1985) reported significantly higher incidence of scabby hip syndrome at 42 days with the increase in stocking density. Jaenisch et al. (2001) have also stated that high stocking densities resulted in greater stress in birds and consequently, in reduced feathering, which increased the incidence of carcass lesions. The process of feathering involves complex physiological mechanisms that are influenced by nutritional, hormonal, genetic and environmental factors, as well as by the interactions between them. Poor feathering is also a preponderant factor in the reduction of the profits in poultry production, by limiting the number of birds to be reared per square meter (Barbi \& Zaviedo, 2000). Such problem is characterized by the reduction in the number of feathers, mostly in the back of birds. Poor feathering occurs in broilers produced in flocks with good performance, neither compromising the weight gain of the affectd bird, nor increasing the mortality rate of the flock. It has been observed that this problem occurs mainly in males reared at high stocking densities, during periods of high temperatures (Coello, 2001). Richards (1971) observed that body temperature in the birds is highly affected by feather covering and might be higher or lower, depending on the feathering score.

Garcia et al. (2002) evaluated the relationship between feathering and incidence of carcass lesions in broiler chickens reared at stocking densities of 10 , 13 and 16 birds $/ \mathrm{m}^{2}$ during the winter and summer. It was reported that there was a reduction in thigh feathering with increasing stocking density at 28, 35 and 42 days of age. As for back evaluations, there were differences only at 35 days. Densities of 10 birds/ $\mathrm{m}^{2}$ resulted in better feathering compared to 13 and $16 \mathrm{birds} / \mathrm{m}^{2}$. At 42 days of age, higher stocking density resulted in poorer feathering in males. The evaluation by feather weight also showed poorer feathering due to higher stocking density in birds at 35 and 42 days of age. These results are corroborated by the present findings, since similar stocking densities have been used in both studies.

According to Richards (1971), the increase in rearing density promotes higher body temperature in birds, and might result in lower feathering rate. Nevertheless, Garcia (2002) has also evaluated broiler chickens reared at 10,13 and $16 \mathrm{birds} / \mathrm{m}^{2}$ from 21 to 42 days of age and reported no differences in body temperature.
Evaluation of Strain, Dietary Energy Level and Stocking Density on Broiler Feathering

This suggests that poorer feathering, as a result of higher density, might not be specifically related to changes in body temperature.

Based on the results shown by different strains in Trials 2 and 4, it seems that the strains commercially available in Brazil show feathering differences, both along the back and the thigh. From the evaluated strains, Cobb 500 and MPK showed better back feathering and thigh feathering, respectively. On the other hand, Hubbard showed poorer feathering. It is worth noting that the latter had better performance, carcass yield and mainly breast yield, but poorer feed conversion (data not shown). MPK and Cobb 500 had poorer performance in the same rearing periods. Therefore, feathering might have influenced the body development of birds. Lowe \& Merkley (1986), Elfadil et al. (1996) and Gous et al. (1999) have also reported differences between strains in regard to feathering parameters. Lowe \& Merkley (1986) evaluated the effects of different genotypes on the feathering rate, independent of the strain effect on growth parameters and nutritional efficiency. Feathering score at 28 days of age was in accordance to the selection for rapid or late feathering; both rapid-feathering males and females showed greater scores and the values persisted from 28 to 52 days of age. The authors have noted that the subjective feathering score was significantly affected $(p<0.05)$ by genotype. Besides, late-feathering males have shown higher body weight and body weight gain, as well as better feed conversion. In the present study, results from Trial 3 have shown that dietary energy levels affected feathering in birds, but only if high stocking density was used. Besides, there were differences between the two systems of evaluation, i.e., score or relative feather weight, due to dietary energy level. The medium energy level promoted better back feathering in 28-day-old birds, whereas birds fed low energy level had better thigh feathering at 35 days of age. Coello (2001) evaluated energy levels in the diet (2825 and $2900 \mathrm{kcal} \mathrm{ME} / \mathrm{kg}$ ) from 1 to 42 days of age and reported that birds fed the diet with lower energy level had greater feather percentages at 21, 35 and 42 days.

Although the effect of sex was not evaluated by score, it was evaluated by means of relative feather weight in Trial 2. Females had better feathering in comparison to males. The absolute values were always greater in females, but this parameter has not been evaluated in the other Trials. 


\section{CONCLUSIONS}

The increase in stocking density from 10 to 16 birds/ $\mathrm{m}^{2}$ reduced feathering in broiler chickens. The reduction was more marked when density was increased from 12 or 13 to 16 birds $/ \mathrm{m}^{2}$.

The broiler strains commercially available in Brazil show different feathering rates. Cobb 500 and MPK show better, and Hubbard poorer, feathering mainly on the back.

Dietary energy level affects feathering in broiler chickens, so that feathering is improved until 28 days of age with medium energy levels. In older birds, higher energy levels do not result in better feathering.

\section{REFERENCES}

Arnold RL, Olsen OE, Carlson CW. Tissue selenium content and serum tocopherols as influenced by dietary type, selenium and vitamin E. Poultry Science 1974; 53:2185-2192.

Barbi JHT, Zaviedo D. Síndrome do mau empenamento de frangos de corte. In: Simpósio Internacional de Ciências Aviárias 2000; 4:4965.

Boone MA, Davidson JA, Reineke EP. Thyroid studies in fast and slow feathering Rhode Island Red chicks. Poultry Science 1950; 29:195-200.

Brake JT. Broiler Productivity: Relationship to Rapid or Slow Feathering. In: 17 Congresso Latinoamericano de Avicultura; 2001; Cidade da Guatemala. Guatemala 1:287-295.

Cahaner A, Deeb N, Gutman M. Effects of the plumage-reducing naked-neck $(\mathrm{Na})$ gene on the performance of fast-growing broilers at normal and high ambient temperature. Poultry Science 1993; 72:767-775.

Cahaner A, Leenstra F. Effects of high temperature on growth and efficiency of male and female broilers from lines selected for high weight gain, favorable feed conversion, and high or low fat content. Poultry Science 1992; 71:1237-1250.

Coello CL. Consideraciones del emplume en pollos de engorda. In: 17 Congresso Latinoamericano de Avicultura; 2001; Cidade da Guatemala. Guatemala; 1:165-173.

Cooper MA, Washburn KW. The relationship of body temperature to weight gain, feed consumption and feed utilization in broilers under heat stress. Poultry Science 1998; 77:237-242.

Edens FW, Parkhurst CR, Havenstein GB, Sefton AE. Housing and selenium influences on feathering in broilers. Journal Applied Poultry Research 2001; 10:128-134.

Edens FW, Carter TA, Parkhurst CR, Sefton AE. Effect of selenium source and litter type on broiler feathering. Journal Applied Poultry Research 2000; 9:407-13.
Edens FW. Empenamento em frangos: Influência de aminoácidos e minerais na dieta In: Conferência APINCO de Ciência e Tecnologia Avícolas; 2000; Campinas, São Paulo. Brasil. p.81-100.

Elfadil AA, Vailllancourt JP, Meek AH. Impact of stocking density, breed, and feathering on the prevalence of abdominal skin scratches in broilers chickens. Avian Diseases 1996; 40(3):546-552.

Garcia RG, Mendes AA, Garcia EA, Naas IA, Moreira J, Almeida ICL, Takita TS. Efeito da densidade de criação e do sexo sobre o empenamento, incidência de lesões na carcaça e qualidade da carne de peito de frangos de corte. Revista Brasileira de Ciência Avícola 2002; 4(1):27-35

Garcia RG. Avaliação do desempenho, características de carcaça e análise econômica da criação de frangos de corte em diferentes densidades [dissertação]. Botucatu (SP): FMVZ/UNESP; 2002.

Gous RM, Moran ET, Stilborn HR et al. Evaluation of the parameters needed to describe the overall growth, the chemical growth, and the growth of feathers and breast muscles of broilers. Poultry Science 1999; 78(6):812-821.

Harrap BS, Woods EF. Species differences in the proteins of feathers. Compedium Biochemistry Physiology 1967; 20:449-460

Jaenisch FR. Mau empenamento. Avicultura Industrial 2001; 91(1086):20-7.

Kuenzel WJ, Kuenzel NT. Basal metabolic rate in growing chicks Gallus domesticus. Poultry Science 1977; 56:619-627.

Leeson S, Walsh T. Feathering in commercial poultry I. Feather growth and composition. World's Poultry Science Journal 2004a; 60:42-51.

Leeson S, Walsh T. Feathering in commercial poultry II. Factors influencing feather growth and feather loss. World's Poultry Science Journal 2004b; 60:52-63.

Lowe PC, Merkley JW. Association of genotypes for rate of feathering in broilers with production and carcass composition traits. Effects of genotypes, sex and diet on growth and feed conversion. Poultry Science 1986; 65:1853-58.

Macari M. Estresse de calor em aves. In: Anais da $38^{\circ}$ Reunião Anual da Sociedade Brasileira de Zootecnia; 2001; Piracicaba, São Paulo. Brasil. 1:686-716.

McDougald LR, Keshavarz K. The effect of polyether ionophore anticoccidial drugs on feather growth in genetically slow-feathering broilers. Poultry Science 1984; 63:1322-1326.

Moran ET. Cystine requirement of feather-sexed broiler chickens with sex and age. Poultry Science 1981; 60:1056-1061.

Proudfoot FG, Hulan W. Effects of stocking density on the incidence of scabby hip syndrome among broiler chickens. Poultry Science 1985; 64:2001-2003.

Richards SA. The significance of changes in the temperatures of the skin and body core of the chicken in the regulation of heat loss. 
Moreira J, Mendes AA, Garcia RG,

Garcia EA, Roça RO, Nääs IA,

Dalanezi JA, Pelícia K

Journal Physiological 1971; 216:1-10.

Rostagno HS, Albino LFT, Donzele JL. et al. Tabelas brasileiras para aves e suínos: composição de alimentos e exigências nutricionais. Viçosa(MG): UFV; 2000.

Sampaio IBM. Estatística aplicada à experimentação animal. Belo Horizonte: Fundação de Ensino e Pesquisa em Medicina Veterinária e Zootecnia, UFMG; 1998.

SAS Institute. SAS User's guide. Cary; 1995. CD ROM.

Yalcin S, Seltar P, Ozkan S, Cahaner A. Comparative evaluation of three commercial broiler stocks in hot vs. temperate climates. Poultry Science 1997; 76:921-929. 